Administrative Issues Journal: Connecting Education, Practice, and Research, Winter 2016, Vol. 6, No. 2: 53-73. doi:10.5929/2016.6.2.4

\title{
Police Attitudes and Professionalism
}

\author{
Joseph Loftus, M.A. \\ Amarillo Police Department \\ Keith Price, Ph.D. \\ West Texas A\&M University, Texas
}

\begin{abstract}
This quantitative study utilized Richard $H$. Hall's attitudinal attributes of a professional using a Likert scale. The survey was administered to officers in two similar mid-sized police departments. The first agency had 650 officers, while the second had 350 officers. Agency One requires all applicants to possess a bachelor's degree, while Agency Two does not have this requirement. It was hypothesized that the officers with a bachelor's degree would possess an enhanced attitudinal level of professionalism over those without. It was also hypothesized that officers belonging to an agency that requires a bachelor's degree will have an enhanced attitudinal level of professionalism over officers from an agency that does not require a bachelor's degree. The findings of the study, like earlier research, did not support a higher attitude of police professionalism associated with a bachelor's degree as posited in the hypotheses. The use of only two agencies may have weakened the strength of the comparison. It may also be that an officer's possession of a bachelor's degree may be desirable for reasons of professionalism, but it lacks an impact on officer's attitudes toward professionalism.
\end{abstract}

Key words: policing, police attitudes about professionalism, police professionalism, policing and education requirements

T he professionalism movement for police officers is said to have begun in 1917 when August Vollmer proposed a thirty-six month college level program in police education. Vollmer believed that higher education would be the vehicle to convert the police occupation into a profession (Shernock, 1992). Throughout the century, several national commissions, such as the Wickersham Commission in 1931 and the President's Commission on Law Enforcement and Administration of Justice in 1967, argued for the benefits of a college-degreed police force. These commissions pointed out that a major component of a profession was the necessity of an education beyond high school (Bostrom, 2005). More recently, the increasing role of community policing has added to the argument for more educated police officers who are more adept at innovation and creativity (Rydberg, 2010). 
Scholars have given several compelling reasons to require a college degree as a prerequisite for police work. They point out that college-degreed applicants will be older, more mature, and will have learned to interact with others who adhere to different belief systems. Students of criminal justice programs will also bring to the job a more in-depth knowledge of the system, its various components and how they function, as well as theories on crime causation. Also, many departments have moved to problemoriented policing. This style of policing requires officers to utilize analytical skills and critical thinking, skills commonly developed in college classrooms (White, 2008).

Despite the long-standing call for a bachelor's degree requirement, most law enforcement agencies still do not require the degree as a pre-requisite for employment. It may be that police departments are reluctant to require a bachelor's degree because there is a lack of evidence to demonstrate that the degree leads to desired outcomes. The recommendations of the commissions were based on intuition, and were not supported by empirical research (Rydberg, 2010).

Several empirical studies have been conducted since the 1970's examining the effects of college education on policing. One study addressed the difference in attitudes between degreed and nondegreed police, specifically examining whether a bachelor's degree had a positive influence in changing police officers' authoritarianism, cynicism, prejudice, and intolerance (Shernock, 1992). Other studies found relationships between college degrees and fewer civilian complaints, shorter response time, fewer injuries and accidents, less likelihood of being assaulted, and more proactive activity (Shernock, 1992). A variety of other benefits have also been associated with higher education for police officers. Studies have shown that a college degree is associated with greater job satisfaction, better communication skills, better job performance, and greater promotion potential, among other benefits (Bumgarner, 2002).

The vast majority of the research that has been conducted since the President's Commission in 1967 sought to answer two questions. Are college-degreed police officers better than their non-degreed counterparts? If they are better, how are they better? Several studies have found college-degreed officers to have higher levels of citizen satisfaction ratings, fewer citizen complaints, and-higher ratings from their superiors, and fewer injuries, preventable accidents, and sick days (Cascio, 1977; Cohen \& Chalken, 1973; Kappeler, 1992; Paoline \& Terrill, 2007). Other researchers have claimed many of these studies were flawed because they relied on official departmental data, supervisory assessments, citizen evaluations, or individual officer perceptions. Critics also claim that pre-service and in-service training may be more effective than a college degree (Eskridge, 1989; Paoline \& Terrill, 2007).

A major criticism in much of the early research of the effects of college education on police is the misconstrued meaning of both college education and of professionalism. Police officers may claim the status of profession, but academic queries do not confirm this assertion (Carlan, 2009). Vollmer was opposed to colleges providing a trade school orientation for police and believed police officers needed a broad-based social science background in order to understand and deal with human aspects of their work more effectively. Many of the performance and-attitude studies in the 1970's did not differentiate the type of education that officers received. Many officers who were the subject of performance studies were enrolled in college programs that appeared to be oriented toward vocational training 
rather than academic education, which has little relation to the liberal arts or the social sciences. The research also failed to distinguish between vocational two-year programs and four-year liberal arts programs (Hudzik, 1978; Scott, 1986). According to many scholars, a two-year vocational program is associated with skilled labor and paraprofessionals, not professionals (Shernock, 1992).

Despite all of the arguments that support the hiring of college-degreed police officers, some law enforcement training instructors continue to criticize the recruitment of officers who have college degrees. The criticism ranges from mere teasing to common statements, such as the importance of street smarts and common sense versus book smarts (Bostrom, 2005). One of the most used arguments against the college degree requirement is "that experience is the greatest teacher for a police officer" (Paoline \& Terrill, 2007). The belief underlying this statement comes from the notion that policing is best learned on the job and all of the necessary performance skills are developed by handling the various situations that arise in policing. While the necessity of on-the-job police training is not in question, requiring a bachelor's degree for police officers is still strongly argued by individuals on both sides of the controversy.

\section{Literature Review}

\section{Performance Based Studies}

In 2007, Paoline and Terrill conducted a study utilizing observational data to examine the impact of education and experience on the use of coercion-both physical force and the verbal aspect of coercion. Coercion was defined as "the means of controlling the conduct of others through threats to harm." The study found that officers with some form of college education relied less on coercive action than officers with only a high school education. The research also found that those officers holding a bachelor's degree were significantly less likely to rely on physical forms of force in their daily encounters with the public, but that, regardless of the educational level of the officer, more experienced officers were less likely to use both physical and verbal force.

A similar study conducted by Rydberg in 2010 examined the impact of higher education on three separate decision making points: arrests, searches, and force. Researchers in two separate cities rode along with a total of 322 different patrol officers over the course of 5,700 hours of observation. The researchers witnessed 11,958 encounters with citizens. During the citizen encounters, 3,356 were with citizens suspected of some manner of wrong-doing. Rydberg found that there was no relationship between officer education and adequacy of probable cause related to arrest and search. Rydberg also found that officers with a four-year degree were significantly less likely to use force relative to nondegreed officers (Rydberg, 2010).

A study conducted by Smith and Aamodt in 1997examined whether education is significantly related to police performance. The study looked at 299 police officers from 12 different municipal police departments. The researchers asked supervisors to evaluate their officers' overall performance, communication skills, public relations, report writing skills, and response to new training. The supervisors rated each officer on an ascending five-point scale. 
The results of the study found that police officers who possess college degrees are better performers than those with only high school diplomas. The study concluded that "increased communication skills, public relations skills, report writing skills, response to new training, decision-making ability, and commitment are all significantly correlated with higher levels of education." The study also found that college-degreed police officers improve their performance as they acquire more experience, while lesser educated officers' performance actually declines. Smith and Aamodt found no relationship between education and the number of times a police officer requires discipline (Smith \& Aamodt, 1997, p. 12).

A longitudinal study conducted by Truxillo, Bennett, and Collins (1998) examined the value of a college degree and police performance over a ten year period. The study examined the work performance of 84 police officers and found that degreed officers showed a statistically significant relationship with promotions and supervisory ratings on job knowledge and that degreed officers were more dependable. The study did not find a relationship between education and disciplinary problems over a ten year period.

Matthew Bostrom (2005) conducted a study to determine if the level of education in police officers is a reliable predictor of their work habits. The data used to determine work habits were commendations, police vehicle traffic collisions, sick time usage, and number of times disciplined. The study showed that the possession of a bachelor's degree did not necessarily correlate with positive work habits. The study went on to examine the type of degree: Bachelor of Arts compared to Bachelor of Science. It was determined that those officers with a Bachelor of Arts degree had better work habits than those with a Bachelor of Science.

\section{Attitudinal Studies}

In addition to performance based studies, numerous other studies have examined police officers' professional attitudes. According to Shernock (1992), "Professionalism is viewed more accurately in terms of attitudinal attributes that reflect the manner in which practitioners view their work" (p. 75).

In 1968, Richard Hall conducted an analysis on the professionalization movement of different occupations. Hall identified two attributes, structural and attitudinal, that occupations acquire in order to move toward a professional model. The structural attributes include a formal education and specific entrance requirements into the occupation. The attitudinal attributes can be seen in how practitioners view their work. If an individual has met the structural requirements of the profession, the next aspect of a professional to be developed is the attitudinal attributes.

Hall (1968) identified five attitudinal attributes of a professional. Professionalism, the first attribute, depends on organizations functioning as a major referent for guiding ideas, standards, and judgments via such mechanisms as journals and meetings. The second attribute was a belief in public service as seen in a conviction that the professional's services are indispensable for societal well-being. The third was a belief in self-regulation: only colleagues have the ability to judge each other's work. The fourth 
attitude was a sense of calling that is seen in a lifetime devotion to the work. The final attitude was autonomy, defined as the freedom to make decisions without interference from others.

Since 1968, other studies have examined police professionalism using Hall's professionalism scale; all of the studies concluded that officers or aspiring officers possess above average professionalism (Carlan, 2009). A study conducted in 1992 by Stanley Shernock examined the effects of college education on patrol officers' views regarding attitudinal attributes identified in the literature on police professionalism. The study surveyed 177 patrol officers from 11 different police departments on the East Coast, specifically examining the effects of college education on patrol officers' orientation toward police issues that are relevant to police professionalism including 1) commitment to the service ideal; 2) discretionary decision making; 3) professional autonomy; 4) the inculcation of ethical values; 5) occupational rather than organizational identity; and 6) commitment to technical efficiency.

Shernock (1992) found that college education is not related strongly to most of the attitudinal attributes of professionalism that have been identified in the literature on police professionalism. Higher education had no significance relation to the service ideal, exercise of discretion, or commitment to technical efficiency. Education was related positively to ethical conduct, yet had no effect on intolerance toward the misconduct of other officers. Education level also related to a less parochial organizational identity. Shernock found that college education "does not enhance the professional behavior of police or change their perspective toward their clients."

J. Bumgarner (2002) conducted a study involving a survey of students enrolled in two- and four-year criminal justice and law enforcement college programs. Bumgarner used two subscales to determine perceptions of policing as a profession, a trade, or a craft. The first subscale was Hall's professionalism scale, consisting of 22 questions relating to the five attitudinal dimensions of professionalism. Hall identified these as service, self-regulation, calling, professional referent, and autonomy. The second scale was a craftsmanship scale, consisting of 28 questions relating to the four dimensions of craftsmanship. These included apprenticeship, holistic work ethic, lack of deference to authority, and oral tradition.

The research sought to answer if students pursuing a four-year liberal arts program in law enforcement have a different perception of policing as a profession than those students enrolled in a two-year program. Bumgarner (2002) found that those students in two-year programs demonstrated "a slightly greater propensity toward a professional orientation of police work than did four year students" ( $p$. 313).

Phillip Carlan's 2009 study surveyed 1,114 officers from 16 different police departments to examine police professionalism using Hall's modified professionalism scale. The study showed that the majority of police officers were basically aligned with Hall's sociological definition of professionalism. The preliminary examination of the surveys revealed officers had above-average professionalism for every demographic group across all five professionalism dimensions. 
An extensive assessment of the data indicated significant professionalism differences among demographic groupings. Education was a significant predictor in three professionalism regression models. Of the officers surveyed, those with a bachelor's degree exhibited significantly higher referent commitment compared to less educated officers. Carlan also found that those with a bachelor's degree were actually less committed to public service than officers without four-year degrees. In addition, officers without a bachelor's degree expressed a significantly higher calling to police work.

Carlan speculated about the reason behind college-educated officers being less committed to public service and expressing a lower calling to police work than their less educated counterparts. He believed that college graduates may have been using police departments as entry jobs pending federal employment, while others were disenfranchised by having spent several years obtaining an advanced degree and witnessing no immediate benefit for it. Carlan believed that the lack of professional recognition for having earned a college degree might lead to unprofessional feelings regarding devotion to an occupation that refuses to recognize the intellectual value of a college degree.

If Carlan is correct, an officer's lack of professional attitude may be attributed to an agency not requiring a degree. It is then assumed that those officers with degrees who work for an agency that require bachelor's degrees will have a higher professional attitudinal level than those without degrees (Carlan, 2009).

\section{Research Questions}

The research-to-date has not clearly shown that college-degreed police officers have more attitudinal attributes of professionalism than those officers who do not possess a degree. A possible reason for this is due to police departments not requiring a bachelor's degree. Those officers who possess a four-year degree may lack feelings of professionalism based on the lack of recognition or benefit they have experienced after obtaining a degree.

The current study continues to seek answers. Do college-degreed officers have an enhanced attitudinal level of professionalism based on Hall's professionalism scale? Is a college degree requirement a factor in an officer's attitude toward professionalism? This study is unique in that it specifically targets two different mid-sized police agencies in Texas that require different criteria for employment. The following hypotheses were tested:

Hypothesis 1: Those officers with a bachelor's degree will possess an enhanced attitudinal level of professionalism over those without.

Hypothesis 2: Officers belonging to an agency that requires a bachelor's degree will have an enhanced attitudinal level of professionalism over officers from an agency that does not require a bachelor's degree. 


\section{Methods}

\section{Sample and Participants}

The first agency, now referred to as Agency One, has approximately 650 officers in a mid-size city connected to a metropolis and surrounded by other cities. The second agency, now referred to as Agency Two, has approximately 350 officers and is in a mid-size city surrounded by mostly rural communities. Agency Two is similar to most agencies within the state of Texas and has no bachelor's degree requirements, while Agency One is exceptional in that it requires all applicants to possess a bachelor's degree.

\section{Assessment and Measures}

A survey was created to determine if the hypotheses were valid. The survey questions were based upon Hall's five attitudinal attributes of a profession using a Likert scale. Hall's attitudinal scale, utilized in numerous studies on attitudes toward professionalism over the years, has been validated and has proven to be reliable over time.

Respondents were asked to select from 1-5 on how strongly they agreed or disagreed on a specific statement, with 1 representing strongly disagree, 2 somewhat disagree, 3 neutral, 4 somewhat agree, and 5 strongly agree. A total of 10 attitudinal questions were asked, one positive and one negative from each of the five attributes.

1. I regularly read police journals or police-related literature.

2. Responding to non-criminal activity such as neighborhood disputes is not an essential purpose for patrol officers.

3. Police officers have a good understanding of the competence and ability of other officers.

4. I wish I had the opportunity to begin a new profession away from policing.

5. At my work, I have the ability to make most of my daily decisions without a supervisor's oversight.

6. I no longer need to seek out or perform training in my current assignment.

7. Police services are essential for society.

8. Police officers should have most of their daily decisions and actions monitored and critiqued by supervisors.

9. Police officers have a true calling to their work.

10. Citizen review boards are the best way to judge a police officer's competence and decision making ability, not fellow officers. 
Questions 1 and 6 relate to professional organizations as a major referent. Questions 2 and 7 relate to service to the public. Questions 3 and 10 relate to the belief in self-regulation. Questions 4 and 9 relate to a sense of calling in the field. Questions 5 and 8 relate to autonomy. The negative questions, $2,4,6,8$, and 10 were reversed after the data was collected to determine the appropriate attitudinal level from each of the five attributes. The highest possible level from each attribute was 10 , and the lowest possible was 2.

\section{Administration of Survey}

To conduct the survey, the primary investigator went to both agencies. Agency One has four separate police stations throughout the city. The primary investigator went to each of the three smaller stations in Agency One before the shift briefing and distributed the surveys to the shift supervisor. The shift supervisors distributed the surveys to the individual officers and then collected the surveys and placed the surveys at the front desk of the station.

In the meantime, the primary investigator went to the largest police station. He personally administered the surveys at this station in order to reduce the impact on police operations. When the officers were finished, he collected the surveys. This cycle began with the midnight shift and continued until all shifts were surveyed.

The next day, the primary investigator collected the surveys from the other three stations. The surveys had been distributed over a 24-hour period. Due to a major incident occurring during the period, the detective division was not available for survey. A liaison from Agency One distributed the remaining surveys to the detective division after the departure of the primary investigator. The liaison then mailed the completed surveys to the primary investigator.

A total of 345 surveys were distributed and 156 were returned. This is a return rate of 45 percent. It should be noted that the primary investigator's inability to personally distribute and collect the surveys may have contributed to a lower return rate.

The principal investigator next went to Agency Two. He distributed the surveys to the field officers in all of the briefings during a 24-hour period. In between shift briefings, he distributed the surveys to the detective division. He distributed a total of 135 surveys in Agency Two and received 123 back. This is a return rate of 91 percent.

\section{Results}

Tables 1a through 1c depict the demographic characteristics for the respondents from both agencies combined. Of the 278 total respondents from this study, the mean age was 37.05 years old, with 11.23 years of police service. Two hundred thirty-nine of the respondents were male, while 39 were female. A total of 199 Officers, 18 Corporals, 45 Sergeants, 12 Lieutenants, and 4 Captains participated in this study. The educational background of the respondents included 17 with high school diplomas, 50 with

LOFTUS \& PRICE / doi:10.5929/2016.6.2.4 
some college hours, 27 with associate degrees, 163 with bachelor's degrees and 21 with master's degrees.

Table 1a

Sex of All Participants

\begin{tabular}{lccc}
\hline Sex & Frequency & Percent & Cumulative Percent \\
\hline Male & 239 & 86.0 & 86.0 \\
Female & 39 & 14.0 & 100.0 \\
\hline Total & 278 & 100.0 & \\
\hline
\end{tabular}

Table 1b

Rank of All Participants

\begin{tabular}{lccc}
\hline Rank & Frequency & Percent & Cumulative Percent \\
\hline Officer & 199 & 71.6 & 71.6 \\
Corporal & 18 & 6.5 & 78.1 \\
Sergeant & 45 & 16.2 & 94.2 \\
Lieutenant & 12 & 4.3 & 98.6 \\
Captain & 4 & 1.4 & 100.0 \\
\hline Total & 278 & 100.0 & \\
\hline
\end{tabular}

Table 1c

Highest Level of Education of All Participants

\begin{tabular}{lccc}
\hline Education Level & Frequency & Percent & Cumulative Percent \\
\hline High School & 17 & 6.1 & 6.1 \\
College Hours & 50 & 18.0 & 24.1 \\
Associate & 27 & 9.7 & 33.8 \\
Bachelor's & 163 & 58.6 & 92.4 \\
Master's & 21 & 7.6 & 100.0 \\
\hline Total & 278 & 100.0 &
\end{tabular}

Tables 2a through $2 \mathrm{c}$ indicate the demographic characteristics of subjects specifically from Agency One and Agency Two. Of the 155 respondents from Agency One, the mean age was 37.43, with 11.29 years of police service. Agency One contained 124 males and 31 females, 125 Officers, 3 Corporals, 18 Sergeants, 6 Lieutenants, and 3 District Chiefs. (Agency One does not have the rank of Captain, so the District Chiefs were labeled as Captain for this study.) The level of education for Agency One included 3 with college hours, 2 with associate degrees, 129 with bachelor's degrees, and 21 with master's degrees. Of the 123 respondents from Agency Two, the mean age was 36.57, with 11.16 years of service. Agency Two contained 115 males and 8 females, 74 Officers, 15 Corporals, 27 Sergeants, 6 Lieutenants, and 1 Captain. The level of education for Agency Two included 17 with high school diplomas, 47 with college hours, 25 with associate degrees, 34 with bachelor's degrees, and 0 with master's degrees. 
Table 2a

Comparison of Participant Sex between Agency One and Agency Two

\begin{tabular}{|c|c|c|c|c|}
\hline Agency & Sex & Frequency & Percent & Cumulative $\%$ \\
\hline \multirow[t]{3}{*}{ One } & Male & 124 & 80.0 & 80.0 \\
\hline & Female & 31 & 20.0 & 100.0 \\
\hline & Total & 155 & 100.0 & \\
\hline \multirow[t]{3}{*}{ Two } & Male & 115 & 93.5 & 93.5 \\
\hline & Female & 8 & 6.5 & 100.0 \\
\hline & Total & 123 & 100.0 & \\
\hline
\end{tabular}

Table $2 b$

Comparison of Participant Rank between Agency One and Agency Two

\begin{tabular}{llccc}
\hline Agency & Rank & Frequency & Percent & Cumulative \% \\
\hline One & Officer & 125 & 80.6 & 80.6 \\
& Corporal & 3 & 1.9 & 82.6 \\
& Sergeant & 18 & 11.6 & 94.2 \\
& Lieutenant & 6 & 3.9 & 98.1 \\
\multirow{4}{*}{ Two } & Captain & 3 & 1.9 & 100.0 \\
\cline { 2 - 5 } & Total & 155 & 100.0 & 60.2 \\
\cline { 2 - 5 } & Officer & 74 & 60.2 & 72.4 \\
& Corporal & 15 & 12.2 & 94.3 \\
& Sergeant & 27 & 22.0 & 99.2 \\
& Lieutenant & 6 & 4.9 & 100.0 \\
\hline
\end{tabular}

Table 2c

Comparison of Participant Level of Education between Agency One and Agency Two

\begin{tabular}{llccc}
\hline Agency & Education Level & Frequency & Percent & Cumulative \% \\
\hline One & High School & 0 & 0 & 0 \\
& College Hours & 3 & 1.9 & 1.9 \\
& Associates & 2 & 1.3 & 3.2 \\
& Bachelor's & 129 & 83.2 & 86.5 \\
& Master's & 21 & 13.5 & 100.0 \\
\hline \multirow{3}{*}{ Two } & Total & 155 & 100.0 & 13.8 \\
\cline { 2 - 5 } & High School & 17 & 13.8 & 52.0 \\
& College Hours & 47 & 38.2 & 72.4 \\
& Associates & 25 & 20.3 & 100.0 \\
& Bachelor's & 34 & 27.6 & \\
\hline
\end{tabular}


In order to test Hypothesis 1, all 278 respondents were examined together based on their educational background, without separating the respondents by their individual agency. These findings are in Table 3a.

Table 3a

Comparison of All Participant Attitudes by Educational Level (Hypothesis 1.1)

\begin{tabular}{|c|c|c|c|c|c|}
\hline Hall's Attitude Variables & Educational Level & $\mathrm{N}$ & Mean & Standard Deviation & Standard Error \\
\hline \multirow[t]{6}{*}{ Referent } & High School & 17 & 7.4118 & 1.73417 & 0.4206 \\
\hline & College Hours & 50 & 7.32 & 1.62179 & 0.22936 \\
\hline & Associate & 27 & 7.3333 & 1.51911 & 0.29235 \\
\hline & Bachelor's & 163 & 7.3252 & 1.77041 & 0.13867 \\
\hline & Master's & 21 & 7.5238 & 1.86062 & 0.40602 \\
\hline & Total & 278 & 7.3453 & 1.71514 & 0.10287 \\
\hline \multirow[t]{6}{*}{ Service } & High School & 17 & 9.2941 & 1.0467 & 0.25386 \\
\hline & College Hours & 50 & 8.38 & 1.276 & 0.18045 \\
\hline & Associate & 27 & 8.2963 & 1.79347 & 0.34515 \\
\hline & Bachelor's & 163 & 8.7239 & 1.33467 & 0.10454 \\
\hline & Master's & 21 & 9.0952 & 1.04426 & 0.22788 \\
\hline & Total & 278 & 8.6835 & 1.35708 & 0.08139 \\
\hline \multirow[t]{6}{*}{ Sense of Calling } & High School & 17 & 8.3529 & 1.69341 & 0.41071 \\
\hline & College Hours & 50 & 8.42 & 1.40102 & 0.19813 \\
\hline & Associate & 27 & 8.1852 & 1.90217 & 0.36607 \\
\hline & Bachelor's & 163 & 8.0184 & 1.73729 & 0.13608 \\
\hline & Master's & 21 & 7.4286 & 1.50238 & 0.32785 \\
\hline & Total & 278 & 8.0827 & 1.68568 & 0.1011 \\
\hline \multirow[t]{6}{*}{ Self-Regulation } & High School & 17 & 7.9412 & 1.47778 & 0.35841 \\
\hline & College Hours & 50 & 8.64 & 1.24146 & 0.17557 \\
\hline & Associate & 27 & 8.8148 & 1.44214 & 0.27754 \\
\hline & Bachelor's & 163 & 8.5399 & 1.21841 & 0.09543 \\
\hline & Master's & 21 & 8.2857 & 1.41926 & 0.30971 \\
\hline & Total & 278 & 8.5288 & 1.28202 & 0.07689 \\
\hline \multirow[t]{6}{*}{ Autonomy } & High School & 17 & 7.8824 & 1.36393 & 0.3308 \\
\hline & College Hours & 50 & 8.7 & 1.29756 & 0.1835 \\
\hline & Associate & 27 & 8.4074 & 1.21716 & 0.23424 \\
\hline & Bachelor's & 163 & 8.1288 & 1.41049 & 0.11048 \\
\hline & Master's & 21 & 7.7143 & 1.61688 & 0.35283 \\
\hline & Total & 278 & 8.2122 & 1.40458 & 0.8424 \\
\hline
\end{tabular}


A Post Hoc test in ANOVA was then utilized to determine if there was a significant difference between the attitudes of the respondents based upon their level of education. These findings are in Table $3 \mathrm{~b}$. The significance level was set at .05 .

Table 3b

Multiple Comparisons of All Participants by Education Level (Hypothesis 1.1)

\begin{tabular}{|c|c|c|c|c|c|}
\hline $\begin{array}{l}\text { Hall's Attitude } \\
\text { Variables }\end{array}$ & $\begin{array}{l}\text { (I)Educational } \\
\text { Level }\end{array}$ & $\begin{array}{l}\text { (J)Educational } \\
\text { Level }\end{array}$ & $\begin{array}{c}\text { Mean } \\
\text { Difference } \\
(\mathrm{I} J) \\
\end{array}$ & $\begin{array}{l}\text { Standard } \\
\text { Error }\end{array}$ & $\begin{array}{l}\text { Significance } \\
\text { Level }\end{array}$ \\
\hline \multirow[t]{4}{*}{ Referent } & \multirow[t]{4}{*}{ Bachelor's } & High School & -0.08661 & 0.4401 & 0.844 \\
\hline & & College Hours & 0.00515 & 0.27915 & 0.985 \\
\hline & & Associate & -0.00818 & 0.35878 & 0.982 \\
\hline & & Master's & -0.19866 & 0.40035 & 0.62 \\
\hline \multirow[t]{4}{*}{ Service } & \multirow[t]{4}{*}{ Bachelor's } & High School & -0.57019 & 0.34192 & 0.097 \\
\hline & & College Hours & 0.34393 & 0.21688 & 0.114 \\
\hline & & Associate & 0.42763 & 0.27874 & 0.126 \\
\hline & & Master's & -0.37131 & 0.31103 & 0.234 \\
\hline \multirow[t]{4}{*}{ Sense of Calling } & \multirow[t]{4}{*}{ Bachelor's } & High School & -0.33454 & 0.4281 & 0.435 \\
\hline & & College Hours & -0.4016 & 0.27154 & 0.14 \\
\hline & & Associate & -0.16678 & 0.349 & 0.633 \\
\hline & & Master's & 0.58983 & 0.38943 & 0.131 \\
\hline \multirow[t]{4}{*}{ Self-Regulation } & \multirow[t]{4}{*}{ Bachelor's } & High School & 0.5987 & 0.32551 & 0.067 \\
\hline & & College Hours & -0.10012 & 0.20647 & 0.628 \\
\hline & & Associate & -0.27494 & 0.26537 & 0.301 \\
\hline & & Master's & 0.25416 & 0.29611 & 0.391 \\
\hline \multirow[t]{4}{*}{ Autonomy } & \multirow[t]{4}{*}{ Bachelor's } & High School & 0.24648 & 0.35356 & 0.486 \\
\hline & & College Hours & -.57117 & 0.22426 & 0.011 \\
\hline & & Associate & -0.27857 & 0.28824 & 0.335 \\
\hline & & Master's & 0.41455 & 0.32163 & 0.199 \\
\hline
\end{tabular}

For referent, the mean was 7.41 for respondents with high school only, 7.32 for respondents with college hours, 7.33 for respondents with an associate's degree, 7.32 for respondents with a bachelor's degree, and 7.52 for respondents with a master's degree. There was no significant difference among any of the respondents for the attitude level of organization functioning as a major referent for guiding ideas, standards, and judgments, such as journals and meetings.

For service, the mean was 9.29 for respondents with only a high school diploma, 8.38 for respondents with college hours, 8.29 for respondents with an associate's degree, 8.72 for respondents with a bachelor's degree, and 9.09 for respondents with a master's degree. There was more of a difference in the respondent's belief in public service as seen in a conviction that their services are indispensable for societal well-being; however, the difference was not significant. 
For a sense of calling, the mean was 8.35 for respondents with high school only, 8.42 for respondents with college hours, 8.18 for respondents with an associate's degree, 8.01 for respondents with a bachelor's degree, and 7.42 for respondents with a master's degree. It appears that the more educated an officer was, the less they felt called to their work. Again, there was no significant difference among respondents based upon their level of education for their sense of calling that is seen in a lifetime devotion to the work.

The mean for self-regulation was 7.94 for respondents with only a high school diploma, 8.64 for respondents with college hours, 8.81 for respondents with an associate's degree, 8.53 for respondents with a bachelor's degree, and 8.28 for respondents with a master's degree. There was no significant difference among respondents belief in self-regulation. These findings produced no support for research Hypothesis 1.

The final professional attitude identified by Hall, autonomy, had a mean of 7.88 for respondents with only a high school diploma, 8.70 for respondents with some college hours, 8.40 for respondents with an associate's degree, 8.12 for respondents with a bachelor's degree, and 7.7 for respondents with a master's degree. There was a significant difference between those respondents with some college hours and those who possessed a bachelor's degree. With the exception of those respondents with only a high school diploma, it appears that those with more formal education actually believe less in the freedom to make decisions without interference from others. This is an inverse finding of Hypothesis 1.

It was proposed that belonging to a specific police agency plays a major role in an individual's attitudes toward their job. To counteract this bias, a second examination of Hypothesis 1 was conducted while separating the subjects by their agency. As can be seen in Tables 4a through 4c, an analysis of the data was conducted while separating the groups by their respective agencies. Of the 155 respondents from Agency One, only five did not possess a bachelor's degree, so the examination was limited to Agency Two. Agency Two had a more evenly distributed education background: 17 had high school diplomas, 47 with some college hours, 25 with associate degrees, and 34 with bachelor's degrees. Examining the referent score of the respondents from Agency Two with only a high school diploma, the mean was 7.41; the respondents with college hours mean was 7.45; the respondents with associate's degrees had a mean of 7.52; and those with bachelor's degrees had a mean of 7.85. While those who possessed a bachelor's degree possessed a larger attitudinal level of organizations functioning as a major referent, there was still not a significant difference among the groups.

The mean service score of respondents from Agency Two with a high school diploma was 9.29, respondents with college hours, 8.27, respondents with an associate's degree, 8.48, and respondents with a bachelor's degree, 8.55 . There was no significant difference among respondents' belief in public service.

The mean sense of calling score of respondents from Agency Two with a high school diploma was 8.35, respondents with college hours, 8.46, respondents with an associate's degree, 8.48, and respondents with a bachelor's degree, 8.24 . There was no significant difference among respondents' sense of calling. 
Table 4a

Comparison of Attitude Scores by Agency (Hypothesis 1.2) - Agency One

\begin{tabular}{|c|c|c|c|c|c|}
\hline $\begin{array}{l}\text { Hall's Attitude } \\
\text { Variables }\end{array}$ & $\begin{array}{l}\text { Level of } \\
\text { Education }\end{array}$ & $\mathrm{N}$ & Mean & $\begin{array}{l}\text { Standard } \\
\text { Deviation }\end{array}$ & $\begin{array}{c}\text { Standard } \\
\text { Error }\end{array}$ \\
\hline \multirow[t]{5}{*}{ Referent } & College Hours & 3 & 5.3333 & 3.21455 & 1.85592 \\
\hline & Associate & 2 & 5 & 1.41421 & 1 \\
\hline & Bachelor's & 129 & 7.186 & 1.74449 & 0.15359 \\
\hline & Master's & 21 & 7.5238 & 1.86062 & 0.40602 \\
\hline & Total & 155 & 7.1677 & 1.80842 & 0.14526 \\
\hline \multirow[t]{5}{*}{ Service } & College Hours & 3 & 10 & 0 & 0 \\
\hline & Associate & 2 & 6 & 5.65685 & 4 \\
\hline & Bachelor's & 129 & 8.7674 & 1.32589 & 0.11674 \\
\hline & Master's & 21 & 9.0952 & 1.04426 & 0.22788 \\
\hline & Total & 155 & 8.8 & 1.39759 & 0.11226 \\
\hline \multirow[t]{5}{*}{ Sense of Calling } & College Hours & 3 & 7.6667 & 1.52753 & 0.88192 \\
\hline & Associate & 2 & 6 & 5.65685 & 4 \\
\hline & Bachelor's & 129 & 7.9612 & 1.76513 & 0.15541 \\
\hline & Master's & 21 & 7.4286 & 1.50238 & 0.32785 \\
\hline & Total & 155 & 7.8581 & 1.78899 & 0.1437 \\
\hline \multirow[t]{5}{*}{ Self-regulation } & College Hours & 3 & 9 & 0 & 0 \\
\hline & Associate & 2 & 6.5 & 4.94975 & 3.5 \\
\hline & Bachelor's & 129 & 8.4729 & 1.26909 & 0.11174 \\
\hline & Master's & 21 & 8.2857 & 1.41926 & 0.30971 \\
\hline & Total & 155 & 8.4323 & 1.34849 & 0.108831 \\
\hline \multirow[t]{5}{*}{ Autonomy } & College Hours & 3 & 7.6667 & 3.21455 & 1.85592 \\
\hline & Associate & 2 & 6 & 1.41121 & 1 \\
\hline & Bachelor's & 129 & 7.9457 & 1.43238 & 0.12611 \\
\hline & Master's & 21 & 7.7143 & 1.61688 & 0.35283 \\
\hline & Total & 155 & 7.8839 & 1.49872 & 0.12038 \\
\hline
\end{tabular}

The mean self-regulation score from Agency Two with a high school diploma was 7.94, respondents with college hours, 8.61, respondents with an associate's degree, 9.00, and respondents with a bachelor's degree, 8.79. There was a significant difference between officers with a bachelor's degree and those with only a high school diploma; however, there was no significant difference between those with a bachelor's and those with some college or an associate's degree. This finding provides some support for research Hypothesis 1.

The mean autonomy score from Agency Two with a high school diploma was 7.88, respondents with college hours, 8.76, respondents with an associate's degree, 8.60, and respondents with a bachelor's degree, 8.82. There was a significant difference between respondents with a bachelor's degree and 
those with only a high school diploma in regards to autonomy; however, there was not a significant difference between those with bachelor's degrees and those with some college or an associate's degree. This finding also provides some support for Hypothesis 1.

Table $4 b$

Comparison of Attitude Scores by Agency (Hypothesis 1.2) - Agency Two

\begin{tabular}{|c|c|c|c|c|c|}
\hline $\begin{array}{l}\text { Hall's Attitude } \\
\text { Variables }\end{array}$ & $\begin{array}{l}\text { Level of } \\
\text { Education }\end{array}$ & N & Mean & Standard Deviation & $\begin{array}{l}\text { Standard } \\
\text { Error }\end{array}$ \\
\hline \multirow[t]{5}{*}{ Referent } & College Hours & 17 & 7.4118 & 1.73417 & 0.4206 \\
\hline & Associate & 47 & 7.4468 & 1.44175 & 0.2103 \\
\hline & Bachelor's & 25 & 7.52 & 1.38804 & 0.27761 \\
\hline & Master's & 34 & 7.8529 & 1.79448 & 0.30775 \\
\hline & Total & 123 & 7.5691 & 1.56855 & 0.14143 \\
\hline \multirow[t]{5}{*}{ Service } & College Hours & 17 & 9.2941 & 1.0467 & 0.25386 \\
\hline & Associate & 47 & 8.2766 & 1.2459 & 0.18173 \\
\hline & Bachelor's & 25 & 8.48 & 1.29486 & 0.25897 \\
\hline & Master's & 34 & 8.5588 & 1.37491 & 0.23579 \\
\hline & Total & 123 & 8.5366 & 1.29496 & 0.11676 \\
\hline \multirow[t]{5}{*}{ Sense of Calling } & College Hours & 17 & 8.3529 & 1.69341 & 0.41071 \\
\hline & Associate & 47 & 8.4681 & 1.39644 & 0.20369 \\
\hline & Bachelor's & 25 & 8.36 & 1.46856 & 0.29371 \\
\hline & Master's & 34 & 8.2353 & 1.63408 & 0.28024 \\
\hline & Total & 123 & 8.3659 & 1.50555 & 0.13575 \\
\hline \multirow[t]{5}{*}{ Self-regulation } & College Hours & 17 & 7.9412 & 1.47778 & 0.35841 \\
\hline & Associate & 47 & 8.617 & 1.27779 & 0.18638 \\
\hline & Bachelor's & 25 & 9 & 0.86603 & 0.17321 \\
\hline & Master's & 34 & 8.7941 & 0.97792 & 0.16771 \\
\hline & Total & 123 & 8.6504 & 1.18725 & 0.10705 \\
\hline \multirow[t]{5}{*}{ Autonomy } & College Hours & 17 & 7.8824 & 1.36393 & 0.3308 \\
\hline & Associate & 47 & 8.766 & 1.127 & 0.16439 \\
\hline & Bachelor's & 25 & 8.6 & 1 & 0.2 \\
\hline & Master's & 34 & 8.8235 & 1.08629 & 0.1863 \\
\hline & Total & 123 & 8.626 & 1.15516 & 0.10416 \\
\hline
\end{tabular}


Table 4c

Multiple Comparisons of Attitude Scores by Agency (Hypothesis 1.2)

\begin{tabular}{|c|c|c|c|c|c|c|}
\hline Agency & $\begin{array}{l}\text { Hall's Attitude } \\
\text { Variables }\end{array}$ & $\begin{array}{c}\text { (I)Educational } \\
\text { Level }\end{array}$ & $\begin{array}{c}\text { (J)Educational } \\
\text { Level }\end{array}$ & $\begin{array}{c}\text { Mean } \\
\text { Difference } \\
(I-J)\end{array}$ & $\begin{array}{l}\text { Standard } \\
\text { Error }\end{array}$ & $\begin{array}{c}\text { Significance } \\
\text { Level }\end{array}$ \\
\hline \multirow[t]{15}{*}{ One } & \multirow[t]{3}{*}{ Referent } & \multirow[t]{3}{*}{ Bachelor's } & College Hours & 1.85271 & 1.04283 & .078 \\
\hline & & & Associate & 2.18605 & 1.27235 & 0.88 \\
\hline & & & Master's & -.33776 & .42017 & .423 \\
\hline & \multirow[t]{3}{*}{ Service } & \multirow[t]{3}{*}{ Bachelor's } & College Hours & -1.23256 & .79362 & .122 \\
\hline & & & Associate & $2.76744^{*}$ & .96830 & .005 \\
\hline & & & Master's & -.32780 & & \\
\hline & \multirow[t]{3}{*}{ Sense of Calling } & \multirow[t]{3}{*}{ Bachelor's } & College Hours & .29457 & 1.04194 & .778 \\
\hline & & & Associate & 1.96124 & 1.27127 & .125 \\
\hline & & & Master's & .53267 & .41981 & .206 \\
\hline & \multirow[t]{3}{*}{ Self-Regulation } & \multirow[t]{3}{*}{ Bachelor's } & College Hours & -.52713 & .78231 & .501 \\
\hline & & & Associate & $1.97287^{*}$ & .95450 & .040 \\
\hline & & & Master's & .18715 & .31520 & .554 \\
\hline & \multirow[t]{3}{*}{ Autonomy } & \multirow[t]{3}{*}{ Bachelor's } & College Hours & .27907 & .87323 & .750 \\
\hline & & & Associate & 1.94574 & 1.06542 & .070 \\
\hline & & & Master's & .23145 & .35183 & .512 \\
\hline \multirow[t]{15}{*}{ Two } & \multirow[t]{3}{*}{ Referent } & \multirow[t]{3}{*}{ Bachelor's } & College Hours & .40613 & .35522 & .255 \\
\hline & & & Associate & .33294 & .41569 & .425 \\
\hline & & & High School & .44118 & .46867 & .348 \\
\hline & \multirow[t]{3}{*}{ Service } & \multirow[t]{3}{*}{ Bachelor's } & College Hours & .28223 & .28565 & .325 \\
\hline & & & Associate & .07882 & .33427 & .814 \\
\hline & & & High School & -.73529 & .37687 & .053 \\
\hline & \multirow[t]{3}{*}{ Sense of Calling } & \multirow[t]{3}{*}{ Bachelor's } & College Hours & -.23279 & .34254 & .498 \\
\hline & & & Associate & -.12471 & .40084 & .756 \\
\hline & & & High School & -.11765 & .45194 & .795 \\
\hline & \multirow[t]{3}{*}{ Self-Regulation } & \multirow[t]{3}{*}{ Bachelor's } & College Hours & .17710 & .26074 & .498 \\
\hline & & & Associate & -.20588 & .30512 & .501 \\
\hline & & & High School & $.85294^{*}$ & .34401 & .015 \\
\hline & \multirow[t]{3}{*}{ Autonomy } & \multirow[t]{3}{*}{ Bachelor's } & College Hours & .05757 & .25372 & .821 \\
\hline & & & Associate & .22353 & .29691 & .453 \\
\hline & & & High School & $.94118^{*}$ & .33475 & .006 \\
\hline
\end{tabular}

*The mean difference is significant at the 0.05 level.

Hypothesis 2 proposed that those officers who are employed in an agency that requires a bachelor's degree would have a higher attitudinal level of professionalism than those who do not. The testing of this hypothesis is found in Tables $5 \mathrm{a}$ and $5 \mathrm{~b}$. The test utilized a one-way ANOVA that examined the five attitudinal levels by agency. 
Table 5a

Comparison of Attitude Scores by Agency (Hypothesis 2)

\begin{tabular}{lccccc}
\hline Hall's Attitude Variables & Agency & $\mathrm{N}$ & Mean & Standard Deviation & Standard Error \\
\hline Referent & One & 155 & 7.1677 & 1.80842 & .14526 \\
& Two & 123 & 7.5691 & 1.56855 & .14143 \\
\cline { 2 - 6 } Service & Total & 278 & 7.3453 & 1.71514 & .10287 \\
\cline { 2 - 6 } & One & 155 & 8.8000 & 1.39759 & .11226 \\
& Two & 123 & 8.5366 & 1.29496 & .11676 \\
\cline { 2 - 6 } Sense of Calling & Total & 278 & 8.6835 & 1.35708 & .08139 \\
\cline { 2 - 6 } & One & 155 & 7.8581 & 1.78899 & .14370 \\
Self-Regulation & Two & 123 & 8.3659 & 1.50555 & .13575 \\
\cline { 2 - 5 } & Total & 278 & 8.0827 & 1.68568 & .10110 \\
\cline { 2 - 5 } Autonomy & One & 155 & 8.4323 & 1.34849 & .10831 \\
& Two & 123 & 8.6504 & 1.18725 & .10705 \\
\cline { 2 - 5 } & Total & 278 & 8.5288 & 1.28202 & .07689 \\
\cline { 2 - 5 } & One & 155 & 7.8839 & 1.49872 & .12038 \\
& Two & 123 & 8.6260 & 1.15516 & .0416 \\
\hline & Total & 278 & 8.2122 & 1.40458 & .08424 \\
\hline
\end{tabular}

Table 5b

Examination of Attitude Scores by Agency (Hypothesis 2)

\begin{tabular}{|c|c|c|c|c|c|c|}
\hline $\begin{array}{l}\text { Hall's Attitude } \\
\text { Variables }\end{array}$ & Groups & $\begin{array}{l}\text { Sum of } \\
\text { Squares }\end{array}$ & $\begin{array}{l}\text { Degrees of } \\
\text { Freedom }\end{array}$ & Mean Square & $\mathrm{F}$ & Significance \\
\hline \multirow[t]{3}{*}{ Referent } & Between Groups & 11.048 & 1 & 11.048 & 3.793 & .052 \\
\hline & Within Groups & 803.801 & 276 & 2.912 & & \\
\hline & Total & 277 & & & & \\
\hline \multirow[t]{3}{*}{ Service } & Between Groups & 4.759 & 1 & 4.759 & 2.599 & .108 \\
\hline & Within Groups & 505.385 & 276 & 1.831 & & \\
\hline & Total & 510.144 & 277 & & & \\
\hline \multirow[t]{3}{*}{ Sense of Calling } & Between Groups & 17.683 & 1 & 17.683 & 6.343 & .012 \\
\hline & Within Groups & 769.414 & 276 & 2.788 & & \\
\hline & Total & 787.097 & 277 & & & \\
\hline \multirow[t]{3}{*}{ Self-Regulation } & Between Groups & 3.264 & 1 & 3.264 & 1.993 & .159 \\
\hline & Within Groups & 452.006 & 276 & 1.638 & & \\
\hline & Total & 455.270 & 277 & & & \\
\hline \multirow[t]{3}{*}{ Autonomy } & Between Groups & 37.772 & 1 & 37.772 & 20.493 & .000 \\
\hline & Within Groups & 508.706 & 276 & 1.843 & & \\
\hline & Total & 546.478 & 277 & & & \\
\hline
\end{tabular}

LOFTUS \& PRICE / doi:10.5929/2016.6.2.4 
For the referent variable, the mean from Agency One was 7.17, while Agency Two had a mean of 7.57. The mean service score from Agency One was 8.8, while Agency Two had a mean of 8.54. The mean for a sense of calling was 7.86 for Agency One, while Agency Two had 8.37. The mean score for selfregulation in Agency One was 8.43, while Agency Two had 8.65. The mean score for autonomy for Agency One was 7.88, while Agency Two had 8.62. While Agency One ranked higher in service, Agency Two ranked higher in referent, a sense of calling, self- regulation, and autonomy. Of these differences, the only significant difference between the two agencies was a sense of calling. Therefore, the findings in only one comparison supported Hypothesis 2.

\section{Discussion}

The findings of this study are similar to other studies regarding police professionalism using Hall's Professionalism Scale (Bumgarner 2002; Carlan 2009; Shernock 1992). Overall, the majority of the respondents are aligned with Hall's sociological definition of professionalism. Officers in this study demonstrated moderate-to-high attitudinal levels of professionalism, regardless of educational background or specific agency to which they belong. While there were differences among the respondents with college education and those without (Hypothesis 1), as well as differences among respondents from separate agencies (Hypothesis 2), the vast majority of those differences were not statistically significant.

\section{Limitations of the Study}

One issue arose during the administration of the survey. A major incident occurred while the primary investigator was at Agency One. Due to this interruption, the primary investigator was unable to retrieve the surveys from the detective division. This might have impacted results since the detective division is filled with more senior officers.

After the primary investigator's departure, he contacted his liaison in Agency One. The liaison distributed the remaining surveys. He also retrieved the completed surveys and mailed them to the primary investigator. The researchers do not believe this action affected the final results. It should be noted, however, that the absence of the primary investigator may have affected the return rate of the surveys.

This study followed Hall's methods, but compared attitudes in only two mid-sized police departments. Comparisons of larger numbers of police agencies may be necessary in order to discover significant differences. Larger numbers of subjects may also be necessary in order to discover differences. The study utilized a large number of pairs, but the single digit status of the group subjects may have reduced the ability to discern any actual effects. Other differences in the two communities may also have affected attitudinal differences. The aspect of rural versus metropolitan communities may have greatly contributed to perceptions and attitudes related to professionalism. 


\section{Need for Further Research}

The overall findings of this study suggest that a bachelor's degree neither increases nor decreases a police officer's overall professional attitudes toward policing. The findings also suggest that an agency that requires all of their officers to possess bachelor's degrees does not significantly change an officer's professional attitudes toward their work. While there may be some benefits to requiring a bachelor's degree for all police officers, as other studies have suggested (Paoline \& Terrill, 2007; Rydberg 2010; Smith 1997), professional attitudes does not appear to be one according to this study.

The following findings were surprising and should be the subject of further research. The research indicated that the more educated an officer, the less they felt called to their work. This finding would seem to be the opposite of expectations. Does additional education remove the mysticism of "a calling to police work?" Is this belief in a calling only true in lesser educated officers? These questions clearly deserve further study in future research.

A second unexpected finding revealed that those with more education were less concerned with the freedom to make decisions without interference. This finding is the inverse of Hypothesis 1 . Why would more educated officers want less freedom in decision-making? There is little doubt that police officer decision making can have serious ramifications for citizens, the officer, and the police agency. The decision to use deadly force is a prime example of this dilemma. Perhaps it is the consequences that may be attached to these decisions that bother educated officers. A deadly force decision can easily lead to job loss, civil liability, or criminal responsibility. These educated officers may want wellresearched standard operating procedures that protect them from liability and shift responsibility to the chief and the agency. Regardless of what is going on, this unusual finding deserves further examination. Future research could offer insight into the relation between education and freedom in decision-making for police officers.

\section{Conclusion}

The findings in this study raises some serious questions about the relationship between professionalism and education in policing. Was Vollmer wrong when he suggested a college-level program in police education in 1917 (Shernock, 1992)?

These findings suggest that policing is more of an occupation than a profession. If this is true, the apprenticeship training found in electrical and plumbing trades is a better model for developing police officers. These training programs produce master electricians and master plumbers who are financially rewarded for their occupational skills but are not considered professionals by society.

In Texas policing, this model already exists under the guidance of the Texas Commission on Law Enforcement (Proficiency Certificates, 2011). Licensing begins with Basic and advances to the highest level, which is also known as Master. One can easily see the similarity between this occupational model and that of electricians and plumbers. 
If policing is only an occupation, then the benefits of a liberal arts education may be wasted. The liberal arts degree produces critical thinking and analysis skills, oral and written communication skills, and the ability to synthesize and make conclusions. Perhaps the expense of acquiring these skills is wasted on future or current police officers.

Other skill-based vocations, however, continue to move toward professionalism by utilizing college education. Teaching requires a bachelor's degree for basic certification. Higher level certificates usually require graduate degrees. The same trend can be found in nursing. There are still Licensed Vocational Nurses and some Registered Nurses with associate degrees. The higher level nursing jobs in allied health generally require a bachelor's degree in nursing. The newest movement is toward the Nurse Practitioner, who possesses a clinical master's degree. The Nurse Practitioner is becoming more common in many areas of allied health.

Should policing remain an occupation similar to electricity and plumbing? This would save many future and current officers significant time and money invested in education. A related question is would the public be satisfied with this level of protective service and law enforcement?

On the other hand, should policing, like education and nursing, pursue professional status by utilizing ever increasing college requirements? More research is clearly indicated to help answer these significant questions about police professionalism.

\section{References}

Bostrom, M. D. (2005). The influence of higher education on police officer work habits. Police Chief, 72(10).

Bumgarner, J. (2002). An assessment of the perceptions of policing as a profession among two year and four year criminal justice and law enforcement students. Journal of Criminal Justice Education, 13, 313-334.

Carlan, P. E., \& Lewis, J. A. (2009). Dissecting police professionalism: A comparison of predictors within five professionalism subsets. Police Quarterly, 12(4), 370-387.

Cascio, W. F. (1977). Formal education and police officer performance. Journal of Police Science \& Administration, 5(1), 89-96.

Cohen, B., \& Chaiken, J. M. (1973). Police background characteristics and performance. Lexington, MA: Lexington Books.

Eskridge, C. (1989). College and the police: A review of the issues. In D. J. Kenney (Ed.), Police and policing: Contemporary issues (pp. 17-25). New York: Praeger.

Hall, R. H. (1968). Professionalization and bureaucratization. American Sociological Review, 33(1), 92104.

Hudzik, J. K. (1978). College education for police: Problems in measuring component and extraneous variables. Journal of Criminal Justice, 669-81. 
Kappeler, V. E., Sapp, A. D., \& Carter, D. L. (1992). Police officer higher education, citizen complaints and departmental rule violations. American Journal of Police, 11, 37-54.

Mannis, J., Archbold, C. A., \& Hassell, K. D. (2008). Exploring the impact of police officer education level on allegations of police misconduct. International Journal of Police Science \& Management, 10(4), 509-523.

Paoline, E.A., \& Terrill, W. (2007). Police education, experience, and the use of force. Criminal Justice Behavior, 34(2), 179-196.

Rydberg, J, \& Terrill, W. (2010). The effect of higher education on police behavior. Police Quarterly, 13(1), 92-120.

Scott, W. (1986). College education requirements for police entry level and promotion: A study. Journal of Police \& Criminal Psychology, 2(1), 10.

Shernock, S. K. (1992). Effects of college education on professional attitudes among police. Journal of Criminal Justice Education, 3, 71-92.

Smith, S. M., \& Aamond, M. G. (1997). The relationship between education, experience, and police performance. Journal of Police and Criminal Psychology, 12(2), 7-14.

Texas Commission on Law Enforcement. (2011, September 1). Proficiency certificates. Retrieved from https://www.texas.gov

Truxillo, D. M., Bennett, S. R., \& Collins, M. L. (1998). College education and police job performance: a ten-year study. Public Personnel Management, 27(2), 269.280.

White, M. D., \& Escobar, G. (2008). Making good cops in the twenty-first century: Emerging issues for the effective recruitment, selection and training of police in the United States and abroad. International Review of Law, Computers \& Technology, 22(1/2), 119-134.

\section{About the Authors}

Joseph Loftus, M.A. (joseph.loftus@amarillo.gov) is currently a Detective Lieutenant at the Amarillo Police Department. He completed his Master of Arts degree in Criminal Justice at West Texas A\&M University. The current study was a directed research project within his graduate studies. Please address correspondence to Joseph Loftus, Amarillo Police Department, 200 S.E. Third Avenue, Amarillo, Texas 79101. Phone: (806) 378-3000.

Keith Price, Ph.D. (kprice@wtamu.edu) is a Professor of Criminal Justice and Sociology at West Texas A\&M University. He is also the Department Head of the Social Sciences departments. Prior to coming to West Texas A\&M University, he spent thirty years serving in the Texas prison system, where he was Warden of five different prison units. Please address correspondence to: Keith Price, West Texas A\&M University, WTAMU Box 60876, Canyon, Texas 79016. Phone: (806) 651-2418. 